This is the final peer-reviewed accepted manuscript of

Bettini S.; Franceschini V.; Astolfi L.; Simoni E; Mazzanti B; Martini A: Revoltella RP: Human mesenchymal stromal cell therapy for damaged cochlea repair in nod-scid mice deafened with kanamycin. CYTOTHERAPY, 20. ISSN 1465-3249

DOI: 10.1016/j.jcyt.2017.11.003

The final published version is available online at: http://dx.doi.org/10.1016/i.jcyt.2017.11.003

Rights / License:

The terms and conditions for the reuse of this version of the manuscript are specified in the publishing policy. For all terms of use and more information see the publisher's website.

This item was downloaded from IRIS Università di Bologna (https://cris.unibo.it/)

When citing, please refer to the published version. 


\title{
Human mesenchymal stromal cell therapy for damaged cochlea repair in nod-scid mice deafened with kanamycin
}

\author{
SIMONE BETTINI ${ }^{1, \star}$, VALERIA FRANCESCHINI ${ }^{1,2, \star}$, LAURA ASTOLFI $^{2,3}$, EDI SIMONI $^{3}$, \\ BENEDETTA MAZZANTI ${ }^{4}$, ALESSANDRO MARTINI ${ }^{2,3} \&$ ROBERTO P. REVOLTELLA ${ }^{2,5}$
}

${ }^{1}$ Department of Biological, Geological and Environmental Sciences, University of Bologna, Bologna, Italy, ${ }^{2}$ Foundation Onlus 'Staminali eVita', Padua, Italy, ${ }^{3}$ Bioacoustics Research Laboratory, Department of Neurosciences, University of Padua, Padua, Italy, ${ }^{4}$ Department of Clinical and Experimental Medicine, University of Florence, Florence, Italy, and

${ }^{5}$ Institute for Chemical, Physical Processes, Centro Nazionale delle Ricerche (C.N.R.), Pisa, Italy

\begin{abstract}
Background. Kanamycin, mainly used in the treatment of drug-resistant-tuberculosis, is known to cause irreversible hearing loss. Using the xeno-transplant model, we compared both in vitro and in vivo characteristics of human mesenchymal stromal cells (MSCs) derived from adult tissues, bone marrow (BM-MSCs) and adipose tissue (ADSCs). These tissues were selected for their availability, in vitro multipotency and regenerative potential in vivo in kanamycin-deafened nod-scid mice. Methods. MSCs were isolated from informed donors and expanded ex vivo. We evaluated their proliferation capacity in vitro using the hexosaminidase assay, the phenotypic profile using flow-cytometry of a panel of surface antigens, the osteogenic potential using alkaline phosphatase activity and the adipogenic potential using oil-red-O staining. MSCs were intravenously injected in deafened mice and cochleae, liver, spleen and kidney were sampled 7 and 30 days after transplantation. The dissected organs were analyzed using lectin histochemistry, immunohistochemistry, polymerase chain reaction (PCR) and dual color fluorescence in situ hybridization (DC-FISH). Results. MSCs showed similar in vitro characteristics, but ADSCs appeared to be more efficient after prolonged expansion. Both cell types engrafted in the cochlea of damaged mice, induc-ing regeneration of the damaged sensory structures. Several hybrid cells were detected in engrafted tissues. Discussion. BMMSCs and ADSCs showed in vitro characteristics suitable for tissue regeneration and fused with resident cells in engrafted tissues. The data suggest that paracrine effect is the prevalent mechanism inducing tissue recovery. Overall, BM-MSCs and ADSCs appear to be valuable tools in regenerative medicine for hearing loss recovery.
\end{abstract}

Key Words: adipose-derived stem cells, bone marrow mesenchymal stromal cells, cochlea, hybrid cells, kanamycin, multipotency, paracrine effect, proliferative capacity, tissue regeneration, xenotransplantation

\section{Introduction}

Deafness is a sensory disability that affects millions of people worldwide. In mammals, deafness is frequently a consequence of various traumas, ototoxic drugs, loud noise or ageing. Deafness in adults is permanent because hair cells and auditory neurons of the organ of Corti (OC) cannot be regenerated after birth. However, recent improvements in stem cell technology have increased studies aimed to prevent or replace lost sensorineural cells, developing regenerative therapies for hearing loss $[1-5]$.
The replacement of sensorineural cells with an exogenous cell source has been recently obtained [2] but further investigations are required [6]. Preliminary studies on cochlear inner ear cell regeneration have been performed in vivo by direct injection of embryonic $[7,8]$, neural [9] or mesenchymal stromal cells (MSCs) $[10,11]$ in cochlear compartments. However, the methods of stem cell administration directly into the cochlea are invasive and unsuitable for clinical applications.

Pluripotent endogenous stem cells were found in thevestibular organ of adult mice, although limited

*These authors are co-first authors.

Corrrespondence: Valeria Franceschini, Department of Biological, Geological and Environmental Sciences, University of Bologna, Via Selmi 3, 40126 Bologna, Italy. E-mail: valeria.franceschini@unibo.it 
to the utricular sensorial epithelium [12]. Among early studies on inner ear cell regeneration, bone marrow and hematopoietic stem cells (HSCs) have been shown to engraft in the inner ear and produce MSCs and fibrocytes [13]. Transplantation of MSCs in the cochlea of a rat model with acute sensorineural hearing loss due to fibrocyte dysfunction favored hearing recovery through regeneration of cochlear fibrocytes [14]. Bone marrow-derived HSCs showed the ability to engraft in the cochlea of mice deafened after ototoxic treatment, but they were not able to spontaneously transdifferentiate into any cochlear cell type and preserved their hematopoietic identity [15]. Recently, CD133+ stem cells isolated from human umbilical cord blood and intravenously (IV) injected into irradiated adult nod-scid mice, deafened by treatment with kanamycin (an ototoxic aminoglycoside) and/or intense acoustic noise, caused a significant cochlear repair, inducing regeneration of endogenous sensory hair cells and neurons [2].

Other studies indicated that the heterogeneous cell population of mesenchymal stroma contained pluripotent MSCs, among which were bone marrow stem cells and adipose-derived stem cells [16]. Transplanted MSC or undifferentiated mesenchymal progenitor cells have been shown able to in vivo engraft in areas of recent physical traumas or chemically induced injuries [17].

The potential of MSCs as repair system for tissues and cells [18] suggested an extension of investigations on the therapeutic ability of MSCs for inner ear repair after acoustic injury. We tested the regenerative ability of human adult mesenchymal cells isolated from bone marrow (BM-MSCs) and adipose-derived stem cells (ADSCs) on a xenotransplanted mouse model, verifying their pluripotent ability in vitro and their ability in vivo to home into the cochlea of acoustically deafened mice and recover the induced tissue damage.

\section{Materials and methods}

\section{Human MSCs}

Isolation and expansion ex vivo BM-MSCs were isolated from bone marrow aspi-rates of three adult donors, who gave their informed consent. The nucleated cell fraction from each BM-MSC sample was obtained using an automated procedure using a SEPAX S-100 machine (Biosafe) as previously described [19]. Briefly, total nucleated cells (TNCs) were seeded in $75 \mathrm{~cm}^{3}$ flasks $\left(1.6 \times 10^{5} / \mathrm{cm}^{2}\right)$ in complete growth medium (CGM), Dulbecco's Modified Eagle's Medium (DMEM)-low glucose (Gibco BRL), supplemented with $2 \mathrm{mmol} / \mathrm{L} \mathrm{L}-$ glutamine, $20 \%$ fetal calf serum (FCS; EuroClone) and $1 \%$ antibiotics in solution (penicillin $100 \mathrm{U} /$ $\mathrm{mL}$, streptomycin $0.25 \mathrm{mg} / \mathrm{mL}$ ). Flasks were incubated at $37^{\circ} \mathrm{C}$ in a humidified atmosphere containing $95 \%$ air and $5 \% \mathrm{CO}_{2}$ (Passage P 0). The MSC expansion was carried out according to published methods $[20,21]$. Briefly, expansion of the cells was obtained with successive cycles of trypsinization and reseed-ing; the expansion was maintained until P12.

Human ADSCs were isolated from subcutane-ous (SC) adipose tissue of eight female donors (aged 2842 years) who gave their informed consent. Fresh lipoaspirates were washed in phosphate-buffered saline (PBS), $\mathrm{pH} 7.3$, then minced in DMEM (Gibco BRL) supplemented with $2 \mathrm{mmol} / \mathrm{L} \mathrm{L}$-glutamine, penicillin $(50 \mu \mathrm{g} / \mathrm{mL})$ and streptomy-cin $(50 \mu \mathrm{g} / \mathrm{mL})$ and digested adding collagenase $(1.5 \mathrm{mg} / \mathrm{mL}$, Sigma) at $37^{\circ} \mathrm{C}$ for $30 \mathrm{~min}$. Fragments were centrifuged ( 300 $g$ for $3 \mathrm{~min}$ ), washed in the same medium containing $10 \% \mathrm{FCS}$, further minced, incubated at $37^{\circ} \mathrm{C}$ and filtered through a $250 \mu \mathrm{m}$ nylon mesh. Erythrocytes were removed using eryth-rocyte lysis buffer (Sigma) and the centrifugation was repeated three times to enrich the ADSC-abundant pellet; approximately $1 \times$ $10^{6}$ TNCs were usually generated from $2 \mathrm{~mL}$ of lipoaspirate. At P0, adherent cells developed into visible colonies $2-3$ days after the initial plating. After 5-7 days in culture, the medium was changed for fresh culture medium fetal calf serum (CM-FCS); the cells were then maintained under conditions identical to those used for BM-MSCs.

When required, cryopreservation was performed after P2: human MSCs from both tissue sources were washed and the pellet suspended in cryopreservation medium containing $20 \%$ FCS and $10 \%$ dimethyl-sulfoxide (DMSO; Sigma). Aliquots were stored at $-80^{\circ} \mathrm{C}$ for the first $24 \mathrm{~h}$ and then in liquid nitrogen.

\section{Proliferation assay}

The BM-MSCs and ADSCs (4 U each) were cultured in CGM up to 60 days. Cells at P2 were used for experiments. Conventional hexosaminidase colorimetric assay was performed to evaluate cell proliferation [20]. Briefly, cells were washed with PBS and soaked in $200 \mu \mathrm{L}$ hexosaminidase substrate, $3.75 \mathrm{mmol} / \mathrm{L} \quad \mathrm{p}$-nitrophenyl-N-acetyl- $\beta-\mathrm{D}$ glucosaminide (Sigma), 0.25\% Triton-X 100 (Sigma) and $0.05 \mathrm{~mol} / \mathrm{L}$ citrate buffer, $\mathrm{pH} 5.0$ (Sigma), and seeded in a 48-well plate. After $1 \mathrm{~h}$ of incubation in a humidified atmosphere containing $5 \% \mathrm{CO}_{2}$ at $37^{\circ} \mathrm{C}$, the reaction was terminated by adding $75 \mu \mathrm{L}$ of 5 $\mathrm{mmol} / \mathrm{L}$ ethylenediaminetetraacetic acid (EDTA) and 50 $\mathrm{mmol} / \mathrm{L}$ glycine, $\mathrm{pH} 10.4$ (Sigma) in each well. The optical density of the supernatant was read in a 96-well plate reader Sirio (SeacSrl), at $405 \mathrm{~nm}$. 


\section{Phenotypic characterization}

The phenotypic profile of MSCs was routinely analysed at P0 and P2 using flow cytometry for expression of a panel of surface antigen markers: CD45 FITC, CD14 PE, CD44 FITC, CD166 PE, CD90 PE, CD73 PE, HLA-DP -DQ -DR FITC, HLA-ABC FITC (BD Pharmingen), CD105 PE (Ancell) and CD271 APC (Miltenyi Biotec S.r.1.). Nonspecific fluorescence and morphological cell parameters were determined by incubation of the same cell aliquot with isotype-matched unrelated mouse immunoglobulin (IgGs) (BD Pharmingen). Flow cytometry was performed by collecting $10^{4}$ events on a FACS Calibur system equipped with a $488 \mathrm{~nm}$ argon laser (Becton Dickinson). Data were analysed using DOT-PLOT bi-parametric diagrams, using CELL QUEST Pro software (Becton Dickinson).

\section{Differentiation potential}

Osteogenic differentiation was induced in human MSCs as previously described [20]. Briefly, $5 \times 10^{4}$ MSCs were incubated in $35-\mathrm{mm}$ diameter dishes in an osteogenic-inducing medium: $10 \mu \mathrm{mol} / \mathrm{L}$ dexamethasone, 50 or $100 \mu \mathrm{mol} / \mathrm{L}$ ascorbate-2-phosphate and $10 \mu \mathrm{mol} / \mathrm{L} \beta$-glycerophosphate (Sigma) supplemented with $2 \mu \mathrm{mol} / \mathrm{L} \mathrm{L-glutamine}$ and $10 \%$ FCS with $1 \%$ antibiotics (OM-FCS). Cultures were maintained in this medium for at least 21 days, at $37^{\circ} \mathrm{C}$, in a humidified atmosphere of $5 \% \quad \mathrm{CO}_{2}$ in air. The medium was replaced twice a week. Osteogenic differentiation was detected by activity of alkaline phosphatase [22] in triplicate samples of MSCs, cultured up to 6 weeks. Cells were washed with PBS and harvested: alkaline phosphatase activity was assayed using the Alkaline Phosphatase Detection Kit (Sigma) and expressed as unit of enzyme per microgram of protein $(\mathrm{U} / \mu \mathrm{g})$. Noninduced cells were assayed as a negative control. Calcium deposition was evaluated using extracellular matrix (ECM) mineral-bound staining, as previously described [23]. Cells were fixed with $70 \%$ ethanol or $10 \%$ formalin solution (Sigma) and stained with $40 \mathrm{mmol} / \mathrm{L}$ alizarin red (Sigma) at $\mathrm{pH}$ 4.1 , for $10 \mathrm{~min}$ at room temperature.

For adipogenic differentiation, human MSCs $\left(5 \times 10^{4}\right.$ cells $)$ were cultured up to $80-90 \%$ confluence in $1.5 \mathrm{~mL}$ CGM in a $35 \mathrm{~mm}$ diameter plastic dish. Adipogenic differentiation was induced by adding to CGM $0.5 \mathrm{mmol} / \mathrm{L}$ 3-isobutyl-1-methylxanthine (Sigma), $50 \mathrm{mmol} / \mathrm{L}$ indomethacin, $1 \mu \mathrm{m}$ insulin and $0.5 \mu \mathrm{mol} / \mathrm{L}$ dexamethasone (Adipogenic Differentiation Medium [ADM]) The ADM was changed every 3 days for 2-3 weeks. Cells were periodically collected, washed and fixed in $10 \%$ formalin solution for 30 min. The accumulation of neutral lipids was detected by incubating cells in $0.5 \%$ oil-red-O (Sigma) at room temperature for $1 \mathrm{~h}$ and placing them in $100 \%$ isopropanol (Sigma) for $15 \mathrm{~min}$. The amount of oilred-O staining was quantified by reading the optical density (OD) at $500 \mathrm{~nm}$ in a 96-well plate reader Sirio (Seac Srl).

\section{Transplantation of human MSCs in an animal model}

\section{Animal model andt reatments}

Two-month-old inbred nod-scid mice (Charles Rivers, Laboratories Clinical) were used. Animals were housed in microisolators and fed sterile food and acidified water to prevent bacterial growth. All animal experiments were performed in compliance with institutional guidelines, according to protocol n.181 (1/9/2006) approved by the Institutional Review Board and the Ethics Committees of the IST of Genoa (IRCCS Azienda Ospedaliera Universitaria San Martino IST-Istituto Nazionale per la Ricerca sul Cancro) and National Research Council (CNR) in Pisa, Italy. We transplanted the human MSCs in nod-scid mice, adapting a xenotransplantation human-mouse model, previously described [24], deafening mice by a treatment with kanamycin (Figure 1). Kanamycin sulphate (Azienda Farmacologica Italiana S.r.1.) was administered subcutaneously at $800 \mathrm{mg} / \mathrm{kg}$ body weight, twice a day for 2 weeks, to induce progressive damage to hearing cells. After the ototoxic treatment, all mice underwent total body irradiation (350 rads, Caesium source) and $24 \mathrm{~h}$ later transplantation was performed IV by injecting in the caudal vein $<1.5 \times 10^{5}$ human MSCs, a dose calculated to avoid the risk of embolism and/or thrombosis. The experimental groups were as follows: BMMSCs (group A, 12 mice) and ADSCs (group B, 12 mice). Controls included mice untreated with kanamycin and transplanted with BM-MSCs or ADSCs (groups C and D, respectively; 10 mice each), mice treated with kanamycin but not transplanted (group E; 6 mice) and mice untreated and not transplanted (group F; 6 mice). From each group, half of the mice were humanely killed 7 days after transplantation and the others 30 days after transplantation. All mice were humanely killed by $\mathrm{CO}_{2}$ inhalation and decapitated. Bullas were opened under a stereomicroscope and the cochlea was exposed. One cochlea was immediately frozen in liquid nitrogen and kept at $-20^{\circ} \mathrm{C}$ for molecular analyses; the second one was opened at the apex and fixed with $5 \mathrm{~mL}$ of Glyofixx (Shandon Lipshaw) overnight at $4^{\circ} \mathrm{C}$ in the dark. Liver, spleen and kidney were also removed from each mouse. Each organ was divided in two parts and prepared according to the same protocols used for the cochleae.

\section{Histology and immunohistochemistry}

Fixed cochleae were washed for $1 \mathrm{~h}$ in $0.1 \mathrm{~mol} / \mathrm{L} \mathrm{PBS}$, $\mathrm{pH} 7.4$, then decalcified in $10 \%$ EDTA solution, $\mathrm{pH}$ 7.4 , for 15 days at $37^{\circ} \mathrm{C}$, daily replacing the EDTA. 

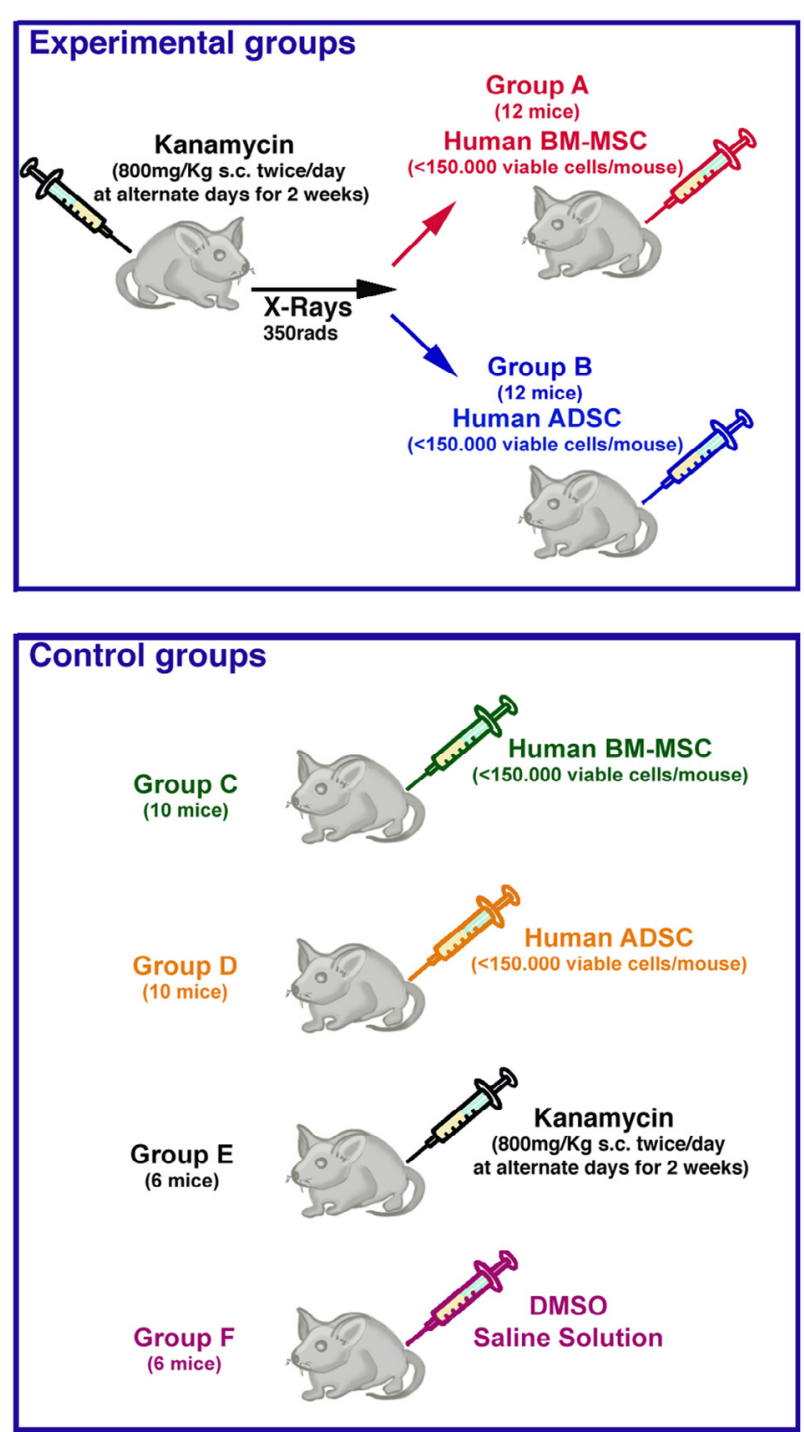

Figure 1. Experimental design.

Afterward, all samples were embedded in Paraplast Plus (Sherwood Medical) at melting point $55-57^{\circ} \mathrm{C}$. Sagittal serial sections of $5 \mu \mathrm{m}$ were collected on silanecoated slides. Sections underwent histological, immunohistochemical and fluorescent in situ hybridization (FISH) analyses.

For histochemistry, sections were deparaffinized, rehydrated, immersed in $1 \% \mathrm{H}_{2} \mathrm{O}_{2}$ (Sigma) to saturate endogenous peroxidase and pretreated in citrate buffer at $\mathrm{pH} 6.0$ for antigen retrieval in microwave for $10 \mathrm{~min}$ at $750 \mathrm{~W}$. Nonspecific binding sites were blocked with $10 \%$ normal goat serum (NGS; Vector Laboratories) before primary antibody incubation overnight at $4^{\circ} \mathrm{C}$ with anti-calretinin $(1: 1000$; $\mathrm{AB} 5054$; Chemicon International), a marker for hair cells and spiral ganglion [25], anti HLA-A/B/C (LY5.1) (1:100; sc-52810; Santa Cruz Biotechnology), anti-Caspase 3 (1:300; ab13847; Abcam), for apoptotic cell detection and anti Proliferating Cell Nuclear Antigen (PCNA; 1:500; P 8825; Sigma). Sections were then incubated for $90 \mathrm{~min}$ in the secondary antibody, horseradish peroxidase (HRP)-conjugated anti-rabbit IgG (1:100; Vector Laboratories) and HRP-conjugated antimouse IgG (1:100; Vector Laboratories), respectively. After treatment with 3,3'-diaminobenzidine (DAB; Sigma), sections were slightly counterstained with Gill's Hematoxylin (Sigma). The slides were rinsed, dehydrated and mounted in Permount (Thermo Fisher Scientific). Negative controls were obtained by replacing the primary antibody by $3 \%$ NGS.

Lectin staining was performed as previously reported [2]. Briefly, for histochemical lectin staining a biotinylated lectin, the Lycopersicon esculentum agglutinin (LEA) $(10 \mu \mathrm{g} / \mathrm{mL}$, Vector Laboratories), and a HRP-conjugated lectin, the Triticum vulgaris agglutinin (WGA) $(10 \mu \mathrm{g} / \mathrm{mL}$; Sigma), were used to detect cochlear tissues. For FISH, to identify transplanted cells the human probe LSI LPL 8p22 SpectrumOrange and LSI C-MYC 8q24.12-24.13 SpectrumGreen human probes (ProVysion, Vysis, ABBOTT Laboratories) were used. Sections from cochleae, liver and kidney were stained with hematoxylin-eosin (HE) (Sigma) for morphological evaluation.

\section{Polymerase chain reaction analysis}

Genomic DNA was extracted from frozen tissues according to the manufacturer's protocol (QIAamp DNA Mini KitH) and analyzed using polymerase chain reaction (PCR) for the presence of human HLADQ $\alpha 1$ as marker for human MSCs, using previously described primers $[2,26]$. Taq Platinum (Invitrogen) was used in all PCR reactions, as recommended by the manufacturer. Single positive PCR bands of the predicted length for HLA-DQ $\alpha 1$ (242 bp) were then cut out of the gel and sequenced using an automatic capillary sequencer (GeneAmp 3110, Big Dye Terminator V 2.0 Cycle Sequencing Ready Reaction Kit, Applied Biosystems). Standard curves were run on murine samples to establish the sensitivity of PCR assays. Dilutions were prepared containing decreasing amounts of human DNA (BM-MSC and ADSC DNA, from 1000 to $1 \mathrm{pg}$ ) in normal mouse DNA, up to $1.0 \mathrm{mg}$ of the total DNA sample. This amplification method using Taq Platinum could detect $1 \mathrm{ng}$ of human DNA in $1 \mu \mathrm{g}$ of mouse DNA, after 40 cycles; this value was assumed as the limit for HLA-DQ $\alpha 1$ DNA detection. To confirm the positive results for human MSC DNA, the presence of two human microsatellite DNA, the short tandem repeats (STR) D8S1179 and D18S51, selected from the Combined DNA Index System (CODIS) commonly used for forensic applications, was tested in organs of two mice, randomly selected from each experimental group, and in those of one mouse from each control group 
(E and F) [27]. STR amplification was performed by single or nested PCR runs, in duplicate, as previously described [14]. The two STRs demonstrated different PCR sensitivity, from $0.1 \mathrm{ng}$ (D8S1179) to $10 \mathrm{ng}$ (D18S51) of human DNA in $1 \mathrm{mg}$ of mouse liver DNA. To improve sensitivity, nested PCR was performed as previously described [28].

Dual color fluoresence in situ hybridization (DC-FISH) Adiacent OC sections from HLA-DQ $\alpha 1$-positive mice were hybridized with human probes to identify transplanted cells, and with human (labeled with FITC) and mouse (labeled with Cy3) pan-centromeric probes (Cambio Ltd) to detect hybrids. After deparaffinization and dehydration, the sections were incubated with Proteinase K/SSC $2 \mathrm{X}(0.25 \mathrm{mg} / \mathrm{mL}$; Roche Diagnostics) at $45^{\circ} \mathrm{C}$ for $5 \mathrm{~min}$, postfixed in $4 \%$ buffered formalin, co-denatured with probes at $80^{\circ} \mathrm{C}$ for $10 \mathrm{~min}$ and incubated overnight at $37^{\circ} \mathrm{C}$. After a stringent wash in $0.3 \% \mathrm{NP} 40 / \mathrm{SSC} 2 \times$ at $75^{\circ} \mathrm{C}$ for $2 \mathrm{~min}$, the samples were stained with DAPI (Kreatech Diagnostics, Leica Biosystems) and mounted. An Olympus BX61 epifluorescence microscope system with a JAI CVM4+ CL digital camera was used for observation, while micrograph analyses were performed with CytoVision 3.7 software (Applied Imaging, Leica Microsystems). Sections from control mice from groups $\mathrm{E}$ and $\mathrm{F}$ were taken as negative controls, and human biopsy specimens as positive controls. The cells positive to human pan-centromeric sequences were counted in the same organ of each mouse, in 4-6 successive tissue sections, at about $20 \mu \mathrm{m}$ of distance. The percentage of positive cells was calculated over the number of all cells counterstained using DAPI.

\section{Image analysis}

Quantification of PCNA- or Caspase 3-positive cells was performed on 10 semi-serial sections for each organ at an interval of $250 \mu \mathrm{m}$. The ImageJ software (v. 1.41o) was used to measure areas and count cells (Cell Counter plug-in).

\section{Statistical analysis}

Each assay was repeated at least four times and all data were expressed as average \pm standard deviation (SD). One-way analysis of variance (ANOVA) was used to assess the differences among multiple groups. Values of $P<0.05$ were considered to be statistically significant (Bonferroni test). The engraftment rates were reported as percentage of positive mice and analyzed with chi-square test.

\section{Results}

At these high doses, kanamycin induces side effects including degeneration of sensitive cells in different tissues, such as liver, spleen, kidney, brain, as well as inner ear cells in the cochlea [2].

For uniformity all mice were total body irradiated, as described above; previous studies showed no histological alterations induced by irradiation [2].

\section{Primary culture of human stem cells}

The BM-MSCs and ADSCs at P2 were both capable of proliferating exponentially without significant differences (Figure 2A). The doubling time for the two cell cultures were analysed up to P12 (Figure 2B): up to P3-P6 was similar, then gradually and significantly increased, with generally uniform fibroblastlike morphology (data not shown). The two cell cultures showed the same doubling time trend. The flow cytometry analyses showed that at P0 and P2 the cell cultures were both negative for the hematopoietic antigens CD45 and CD14, while they were moderately positive for HLA-DQ-DP-DR and CD271 at P0. Both cell cultures were positive for the following panel of MSC-specific surface antigen markers: CD44, CD166, CD90, CD73, HLA-ABC and CD166 (Figure 2C). Thus, BM-MSCs and ADSCs displayed a high degree of homogeneity for cell surface markers at initial passages $\mathrm{P} 0$ and $\mathrm{P} 2$.

\section{Osteogenic and adipogenic differentiation}

To verify the multilineage capacity of both cell cultures, the fibroblast-like cells were induced to differentiate toward osteogenic and adipogenic lineages, using lineage-specific inducing factors. For example, the differentiation of BM-MSCs at P2, grown in OM-FCS, was induced rapidly. Within the first week of culture, the cells began to undergo morphological changes from an initial spindle-shape (Figure 3A) to a more large-polygonal appearance. Cells tended to form tightly packed colonies, having dense, granular areas within individual colonies, forming multiple layers of cells after 2-3 weeks in culture. Dense nodules tended to originate from these colonies, and these released elongated cells with larger nuclei. Differentiated cells were identified by staining with alizarin red (Figure 3B). Changes in cellular morphology were accompanied by a progressive, significant increase in alkaline phosphatase activity (Figure 3D). The activity of this enzyme was generally negligible in noninduced MSC controls, indicating a low level of endogenous activation. In the first week, both cell cultures showed an induced osteogenic differentiation, but only that of BM-MSCs was significant. After 2 weeks, the number of BM-MSC colonies undergo-ing osteogenic differentiation decreased, whereas the number of ADSC ones significantly increased in comparison with both BM-MSCs and control. Finally, after 


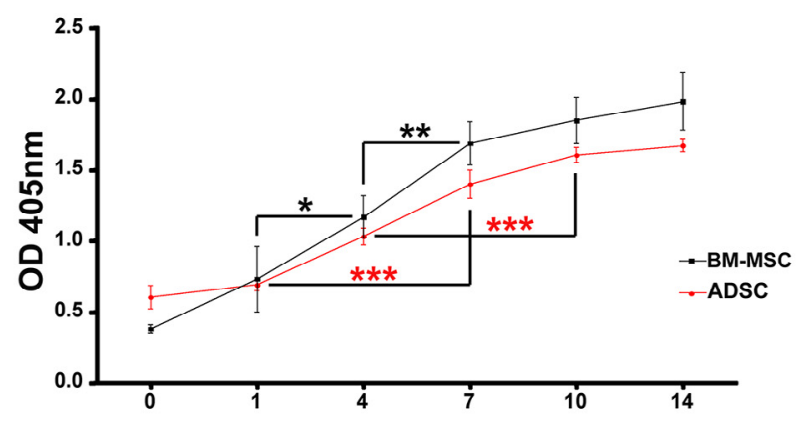

A

days

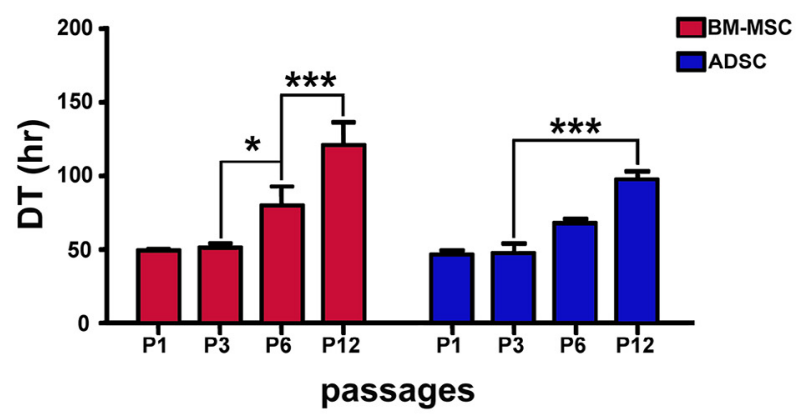

B

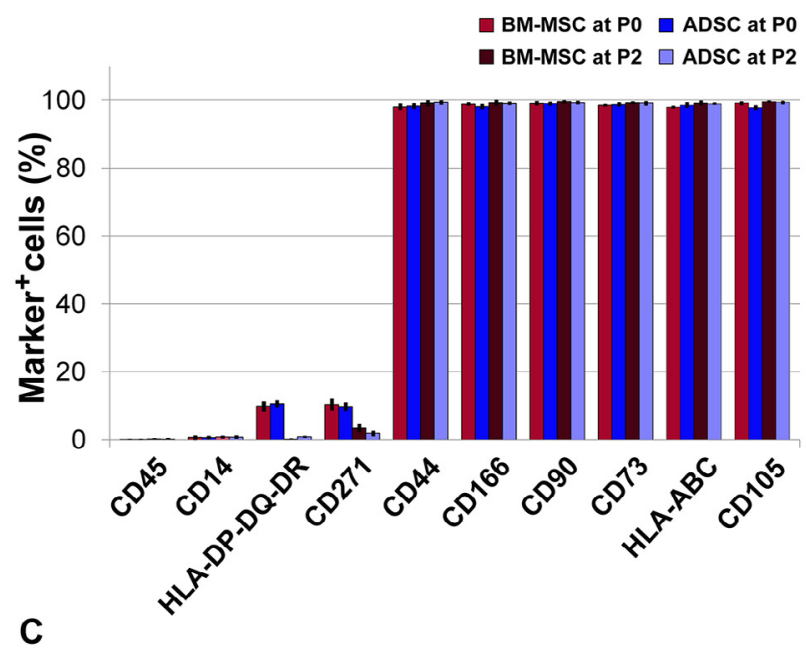

Figure 2. Growth kinetics and phenotypic characterization of human MSCs. (A) Proliferation rate of BM-MSCs and ADSCs up to 14 days of culture. OD, optical density. (B) Doubling time (DT) of BM-MSCs and ADSCs up to P12. (C) Phenotypic characterization using flow cytometry of surface markers of BM-MSCs and ADSCs. Asterisks indicate significant differences $\left({ }^{\star} P<0.05\right.$; $\left.{ }^{\star \star} P<0.01 ;{ }^{\star \star \star} P<0.001\right)$.

3 weeks only ADSCs appeared to maintain osteogenic capability.

The adipogenic differentiation capability was similar for both cell types at P2 (Figure 3E), but was significantly higher for ADSCs at the 4th day. For example, multiple intracellular droplets filled with lipids were
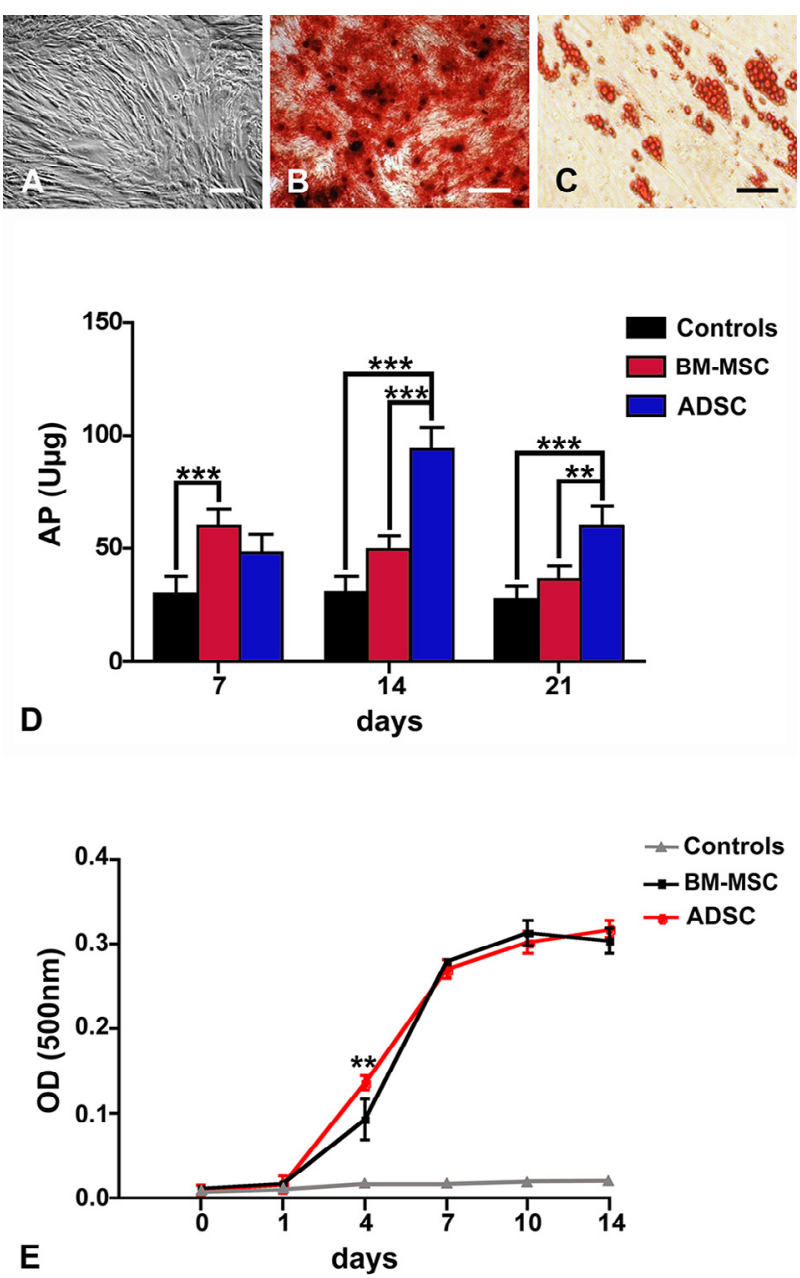

Figure 3. Differentiation potential of human MSCs at P2. (A) Morphology of undifferentiated BM-MSCs. (B) BM-MSCs stained with alizarin red S, showing osteogenic differentiation. (C) BM-MSCs stained with oil red $\mathrm{O}$, showing adipogenic differentiation. (D) Alkaline phosphatase (AP) activity showing osteogenic differentiation in both human MSCs; values are expressed as nanomoles of p-nitrophenol produced for minute per microgram of protein (U/ $\mu \mathrm{g}$ ). (E) Amount of oil-red-O staining showing adipogenic differentiation, measured using OD at $500 \mathrm{~nm}$ in both human MSCs. Controls were grown in noninducing medium. Scale bars: $100 \mu \mathrm{m}$ (A) and (C); $200 \mu \mathrm{m}(\mathrm{B})$. Asterisks indicate significant differences as in Figure 2.

visible in $30-50 \%$ of the cells maintained in $\mathrm{ADM}$ (Figure 3C). The lipid droplets were detected after 6-8 days of induced differentiation and very few small lipid droplets were observed in controls of both cell cultures (data not shown).

In vivo regeneration

In nod-scid mice of control group F the OC showed normal morphology and cytoarchitecture (OC): the hair cells, supporting cells, auditory neurons and spiral ganglion cells all had a normal shape (Figure 4A). In contrast, mice from group $\mathrm{E}$, pretreated with kanamycin 

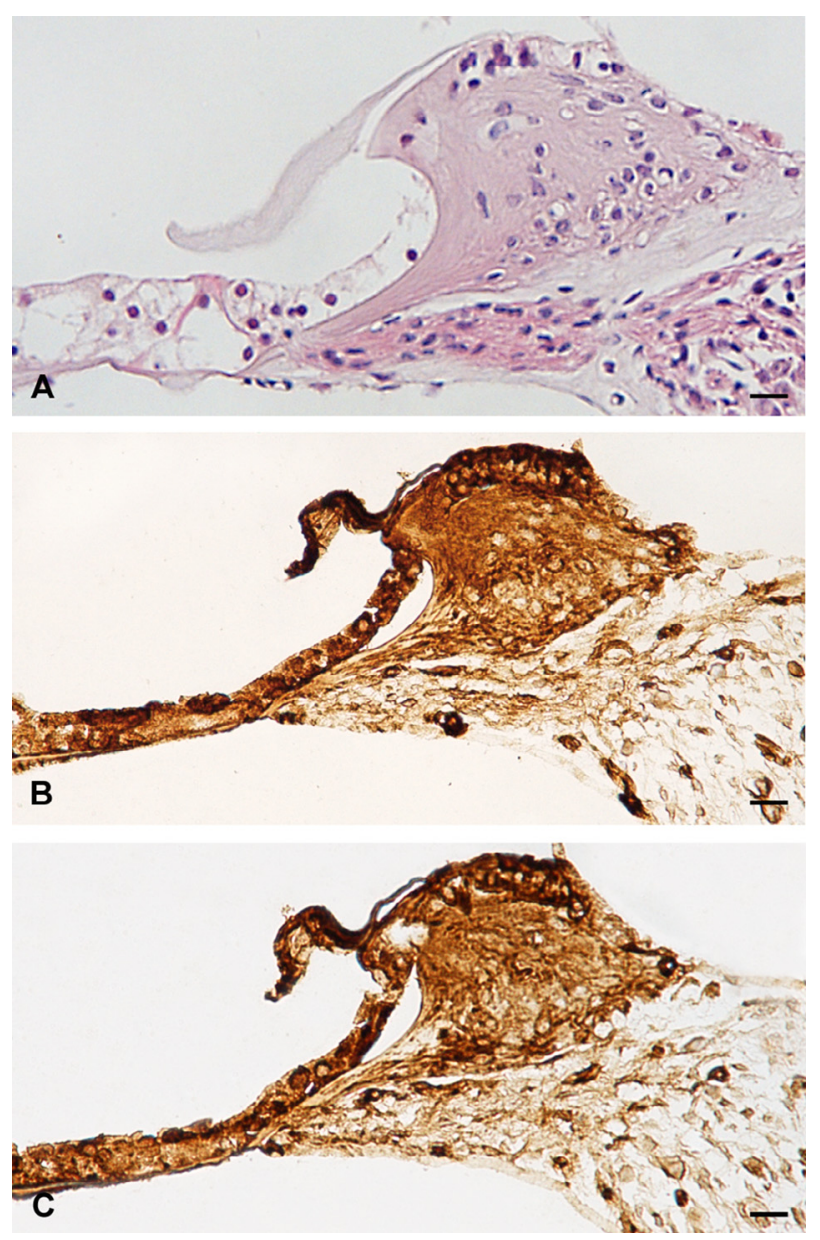

Figure 4. Cochlear damage induced by kanamycin in nod-scid mice. (A) Section of OC from a control untreated mouse (group F), stained with hematoxylin-eosin. (B) Section of OC from a group E mouse, stained with LEA. (C) Section of OC from a group E mouse, stained with Triticum vulgaris agglutinin (WGA). Scale bars: $20 \mu \mathrm{m}$.

but not transplanted with MSCs, showed a severely damaged OC with marked loss of cochlear fibrocytes, hair cells, supporting cells and neurons at 7 days from the ototoxic treatment (Figure 4B and 4C). All kanamycin-treated and transplanted mice (groups A-B) showed tissue regeneration and cochlear repair 30 days after MSC transplantation. The OC from a group B mouse, transplanted with ADSCs, is shown in Figure 5; staining using wheat germ agglutinin (WGA), Lycopersicon esculentum agglutinin (LEA) and calretinin revealed that the basilar membrane and the sensory and supporting cells were regenerated and their morphology was similar to control mice of group F. The tectorial membrane, the modiolus cells and the vestibular membrane of Reissner recovered their morphology (data not shown). Cochleae from all mice were qualitatively evaluated and the repair scores are summarized in Table I; about $50 \%$ of kanamycin treated-ADSC/BM-MSC transplanted mice appeared
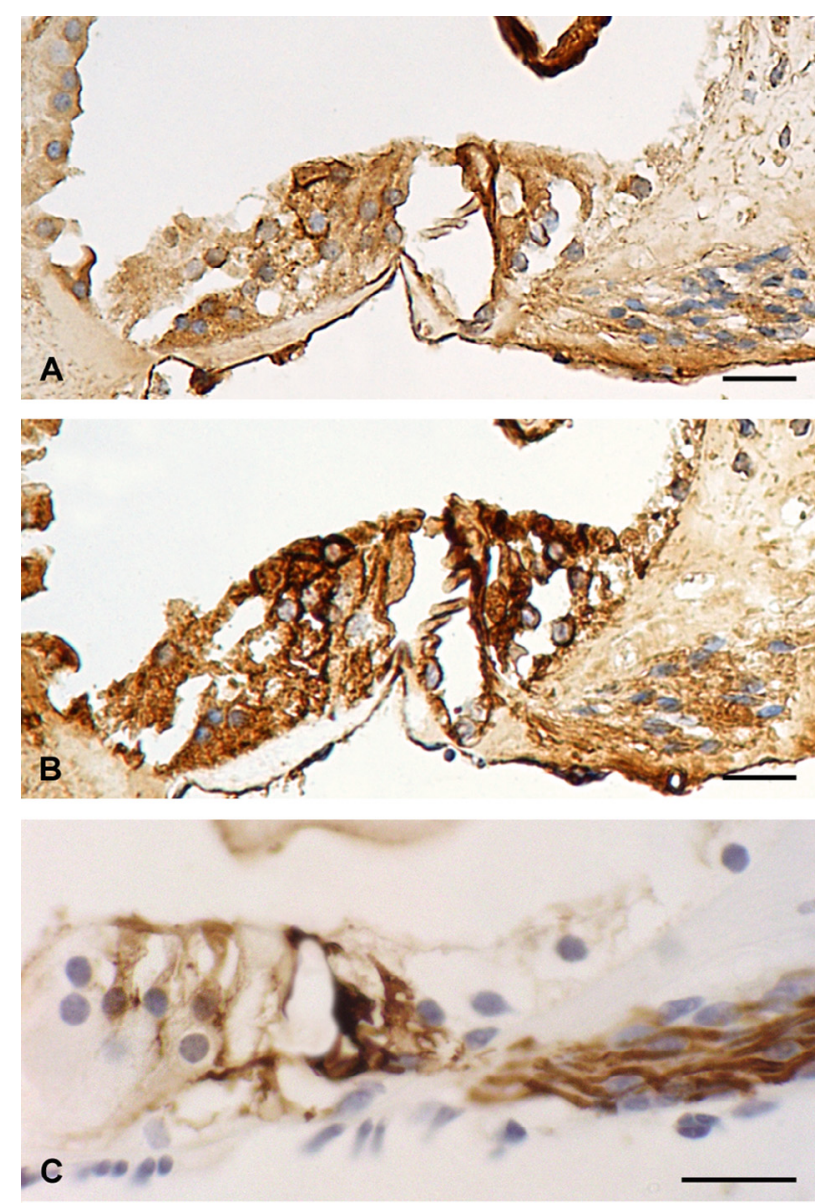

Figure 5. Repair of cochlear damage by ADSCs in mice from group B. (A) Section of OC stained with WGA. (B) Section of OC stained with LEA. (C) Section of OC immunostained with calretinin. Scale bars: $20 \mu \mathrm{m}$.

completely regenerated, and all other mice showed at least a partial recovery.

\section{Detection of human stem cells in transplanted mice}

All mice transplanted with MSCs (groups A-D) revealed human DNA in vivo using PCR analysis of the HLA-DQ $\alpha 1$ DNA marker in kidney, liver, spleen and cochlea (Figure 6A and 6B). Table II summarizes the amount of HLA-DQ $\alpha 1$ DNA for each animal in the different tissues; at 7 days post-transplantation, the presence of the marker appeared more easily detectable than at 30 days.

The success of transplantation of MSCs was confirmed also using electropherograms for two specific human STRs (STR D21S11 and STR D18S51; Figure 6C) in transplanted mice, whereas human DNA was never detected in nontransplanted controls. The percentage of mice positive to human DNA detection was significantly higher in mice pretreated with kanamycin than in non-pretreated ones for both cell lines (Figure 6D). 
Table I. Visual scoring and interpretation of morphological repair in the OC.

\begin{tabular}{|c|c|c|c|}
\hline Group & Treatment & Mouse & Score \\
\hline \multirow[t]{12}{*}{ A } & \multirow[t]{12}{*}{ Kanamycin + BM-MSCs } & $1(7 \mathrm{~d})$ & 2 \\
\hline & & $2(7 \mathrm{~d})$ & 1 \\
\hline & & $3(7 d)$ & 1 \\
\hline & & $4(7 \mathrm{~d})$ & 2 \\
\hline & & $5(7 \mathrm{~d})$ & 2 \\
\hline & & $6(7 \mathrm{~d})$ & 2 \\
\hline & & $7(30 d)$ & 1 \\
\hline & & $8(30 \mathrm{~d})$ & 2 \\
\hline & & $9(30 \mathrm{~d})$ & 1 \\
\hline & & $10(30 \mathrm{~d})$ & 2 \\
\hline & & $11(30 \mathrm{~d})$ & 1 \\
\hline & & $12(30 \mathrm{~d})$ & 1 \\
\hline \multirow[t]{12}{*}{ B } & \multirow{12}{*}{ Kanamycin + ADSCs } & $1(7 \mathrm{~d})$ & 2 \\
\hline & & $2(7 \mathrm{~d})$ & 2 \\
\hline & & $3(7 \mathrm{~d})$ & 1 \\
\hline & & $4(7 \mathrm{~d})$ & 1 \\
\hline & & $5(7 \mathrm{~d})$ & 2 \\
\hline & & $6(7 \mathrm{~d})$ & 2 \\
\hline & & $7(30 \mathrm{~d})$ & 1 \\
\hline & & $8(30 d)$ & 1 \\
\hline & & $9(30 \mathrm{~d})$ & 2 \\
\hline & & $10(30 \mathrm{~d})$ & 1 \\
\hline & & $11(30 \mathrm{~d})$ & 2 \\
\hline & & $12(30 \mathrm{~d})$ & 2 \\
\hline \multirow[t]{10}{*}{$\mathrm{C}$} & \multirow[t]{10}{*}{ No Kanamycin + BM-MSCs } & $1(7 \mathrm{~d})$ & 2 \\
\hline & & $2(7 \mathrm{~d})$ & 2 \\
\hline & & $3(7 \mathrm{~d})$ & 2 \\
\hline & & $4(7 \mathrm{~d})$ & 2 \\
\hline & & $5(7 d)$ & 2 \\
\hline & & $6(30 d)$ & 2 \\
\hline & & $7(30 \mathrm{~d})$ & 2 \\
\hline & & $8(30 d)$ & 2 \\
\hline & & $9(30 \mathrm{~d})$ & 2 \\
\hline & & $10(30 \mathrm{~d})$ & 2 \\
\hline \multirow[t]{10}{*}{$\mathrm{D}$} & \multirow[t]{10}{*}{ No Kanamycin + ADSCs } & $1(7 \mathrm{~d})$ & 2 \\
\hline & & $2(7 \mathrm{~d})$ & 2 \\
\hline & & $3(7 \mathrm{~d})$ & 2 \\
\hline & & $4(7 \mathrm{~d})$ & 2 \\
\hline & & $5(7 \mathrm{~d})$ & 2 \\
\hline & & $6(30 \mathrm{~d})$ & 2 \\
\hline & & $7(30 \mathrm{~d})$ & 2 \\
\hline & & $8(30 d)$ & 2 \\
\hline & & $9(30 \mathrm{~d})$ & 2 \\
\hline & & $10(30 \mathrm{~d})$ & 2 \\
\hline
\end{tabular}

Score: 0 , no recovery; 1 , partial recovery (lack of one or more rows of hair cells, abnormalities in the tunnel of Corti, absence of calretinin-positivity); 2, complete recovery (normal structure compared with control untreated mice). Group E mice showed no recovery (0), whereas group $\mathrm{F}$ mice showed no morphological alteration (2).

After 7 days from transplantation, HLA-ABC was detected using immunohistochemical analyses in kidney (Figure 7A and 7B), liver (Figure 7C), spleen (Figure 7D) and cochlea (Figure 7E and 7F) of mice from groups $\mathrm{A}$ and $\mathrm{B}$, and no expression in control nontransplanted mice (groups $\mathrm{E}$ and $\mathrm{F}$ ). Positive immunostaining was mostly detected in pericytes surrounding endothelial cells of small capillaries. Con-

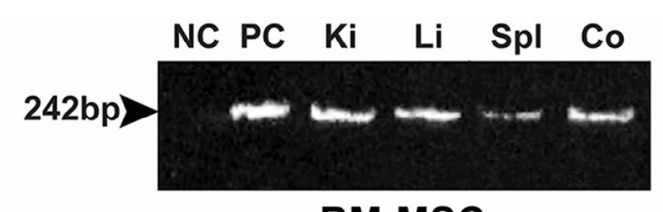

A

BM-MSC

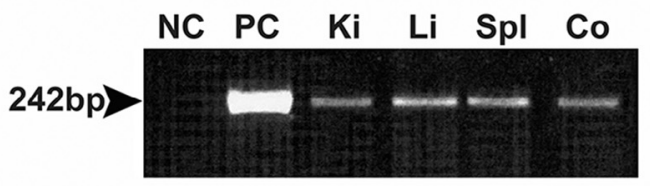

B

ADSC
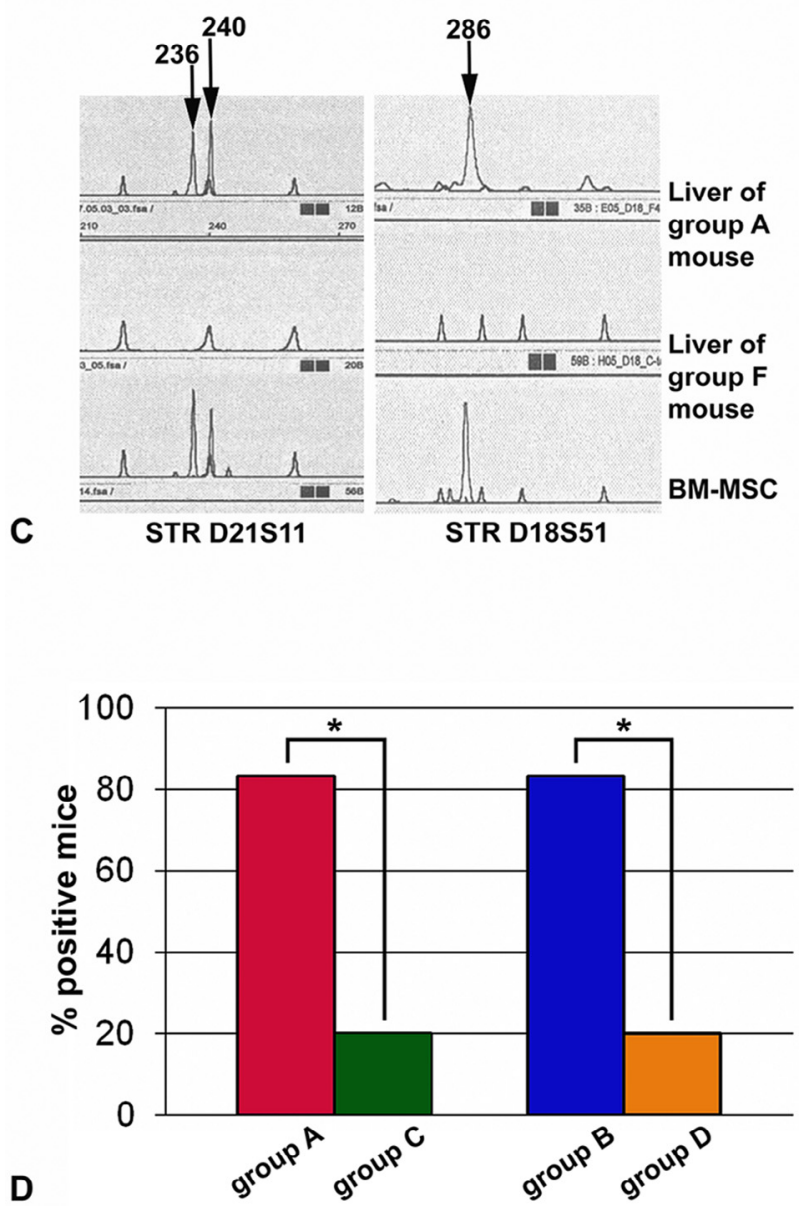

Figure 6. Detection of human MSCs in transplanted mice. (A) Detection of HLA-DQ $\alpha 1$ using PCR in different organs of group A mice, 30 days after transplantation. (B) Detection of HLA-DQ $\alpha 1$ using PCR in different organs of group B mice, 30 days after transplantation. NC, negative control (spleen from group F mice); PC, positive control (human cord blood); Ki, kidney; Li, liver; Spl, spleen; Co, cochlea. (C) Detection of human microsatellites STR D21S11 and STR D18S51 in livers of mice from groups A and F. BMMSCs, positive control cells. Arrows indicate the length of human microsatellites (bp). (D) Percentage of mice from the different groups positive to engraftment in the cochlea. Asterisks indicate significant differences $(P<0.05)$. 
Table II. Visual scoring and interpretation of band intensity of HLA.DQ $\alpha 1$ PCR signal.

\begin{tabular}{|c|c|c|c|c|c|c|}
\hline Group & Treatment & Mouse & Liver & Cochlea & Spleen & Kidney \\
\hline \multirow[t]{12}{*}{ A } & \multirow[t]{12}{*}{ Kanamycin + BM.MSC } & 1 (7 days) & ++ & ++ & + & - \\
\hline & & 2 (7 days) & + & + & - & + \\
\hline & & 3 (7 days) & ++ & ++ & + & + \\
\hline & & 4 (7 days) & ++ & + & + & + \\
\hline & & 5 (7 days) & + & ++ & - & + \\
\hline & & 6 (7 days) & + & + & - & + \\
\hline & & 7 (30 days) & + & + & - & + \\
\hline & & 8 (30 days) & + & - & - & - \\
\hline & & 9 (30 days) & ++ & + & + & + \\
\hline & & 10 (30 days) & + & + & + & + \\
\hline & & 11 (30 days) & + & + & - & + \\
\hline & & 12 (30 days) & + & + & - & - \\
\hline \multirow[t]{12}{*}{ B } & \multirow[t]{12}{*}{ Kanamycin + ADSC } & 1 (7 days) & ++ & ++ & + & ++ \\
\hline & & 2 (7 days) & ++ & + & - & + \\
\hline & & 3 (7 days) & + & ++ & + & ++ \\
\hline & & 4 (7 days) & + & + & - & + \\
\hline & & 5 (7 days) & ++ & - & + & + \\
\hline & & 6 ((7 days) & ++ & + & - & + \\
\hline & & 7 (30 days) & + & + & - & + \\
\hline & & 8 (30 days) & + & + & + & + \\
\hline & & 9 (30 days) & + & + & - & - \\
\hline & & 10 (30 days) & + & + & - & - \\
\hline & & 11 (30 days) & + & + & + & + \\
\hline & & 12 (30 days) & + & - & - & + \\
\hline \multirow[t]{10}{*}{$\mathrm{C}$} & \multirow[t]{10}{*}{ No Kanamycin + BM.MSC } & 1 (7 days) & + & + & - & + \\
\hline & & 2 (7 days) & + & - & + & - \\
\hline & & 3 (7 days) & - & - & - & - \\
\hline & & 4 (7 days) & + & - & - & + \\
\hline & & 5 (7 days) & + & + & - & - \\
\hline & & 6 (30 days) & - & - & - & + \\
\hline & & 7 (30 days) & - & - & - & - \\
\hline & & 8 (30 days) & + & + & + & + \\
\hline & & 9 (30 days) & - & - & - & - \\
\hline & & 10 (30 days) & + & - & - & + \\
\hline \multirow[t]{10}{*}{$\mathrm{D}$} & \multirow[t]{10}{*}{ No Kanamycin + ADSC } & 1 (7 days) & + & + & + & - \\
\hline & & 2 (7 days) & + & - & + & + \\
\hline & & 3 (7 days) & + & + & - & + \\
\hline & & 4 (7 days) & + & - & - & + \\
\hline & & 5 (7 days) & - & - & + & - \\
\hline & & 6 (30 days) & + & + & - & + \\
\hline & & 7 (30 days) & + & - & - & - \\
\hline & & 8 (30 days) & + & - & - & - \\
\hline & & 9 (30 days) & - & - & + & + \\
\hline & & 10 (30 days) & + & - & - & - \\
\hline
\end{tabular}

Group E and F mice showed no engraftment. Score: (-), no signal; (+), positive signal; (++), strong positive signal.

cerning the inner ear, faint positive staining for HLA$\mathrm{ABC}$ was detected in the modiolus (Figure 7E), in the lateral wall (including stria vascularis and spiral ligament) and in proximity of small capillaries (Figure 7F), but never among hair cells and spiral ganglion neurons in OC (data not shown).

The immunohistochemical results support those obtained using DNA and morphological analyses, showing that in the cochlea only kanamycin pretreated groups ( $\mathrm{A}$ and $\mathrm{B}$ ) were positive to human cell markers. After 30 days from transplantation, no positivity to HLA-ABC was observed.
Thirty days after MSC transplantation, DCFISH analysis was performed to detect evidence of chimerism, scoring pan-centromeric DNA sequences specific for human and mice in mononuclear cells in different mouse tissues. Less than $1.5 \%$ of mononuclear cells were positive to human DNA staining in the cochlea (Figure 8A). These cells reacted with both human and mouse pan-centromeric DNA probes in the nucleus, suggesting that human MSCs fused with resident cells. Engrafted hybrid BMMSCs appeared more numerous than ADSCs (Table III); the number of human cells was higher in 

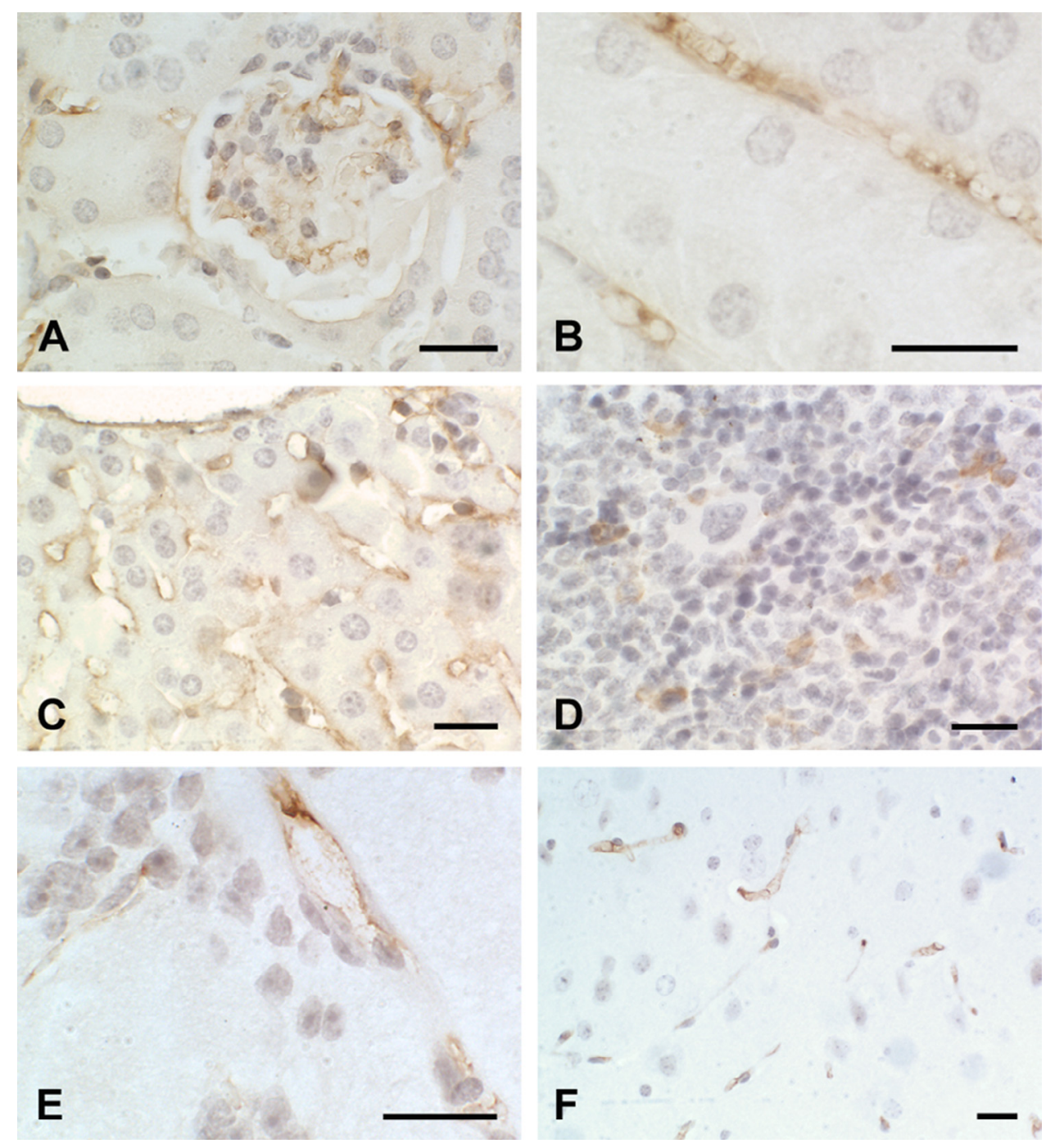

Figure 7. Immunohistochemical detection of human MSCs using anti-human HLA-ABC antibody staining in different tissues of mice from group A, 7 days after transplantation. (A) Kidney glomerulus. (B) Kidney tubule. (C) Liver. (D) Spleen. (E-F) Cochlear modiolus. Scale bars: $20 \mu \mathrm{m}$.

Table III. DC-FISH analysis in the OC of nod-scid mice at 30 days after human stem cells IV transplantation.

\begin{tabular}{lccc}
\hline & No. of ears & Total cells counted $^{\mathrm{a}}$ & Hybrid cells (\%) \\
\hline Group A & 6 & 1840 & $21(1.14 \%)$ \\
Group B & 6 & 2200 & $12(0.55 \%)$ \\
Group C & 5 & 2036 & $3(0.15 \%)$ \\
Group D & 4 & 1840 & $4(0.22 \%)$ \\
Group E & 6 & 1400 & 0 \\
Group F & 6 & 1520 & 0 \\
\hline
\end{tabular}

${ }^{a}$ Cell counts were made on $4-6$ sections, at about $20 \mu \mathrm{m}$ distance, for each cochlea; total cells counterstained using DAPI were counted. Significant differences $(P<0.05)$ : Group A-Group B; Groups C/D-Groups E/F; Group B-Groups C/D; Group A-Groups C/D. Groups C and D were not significantly different, as Groups $\mathrm{E}$ and $\mathrm{F}$. kanamycin-treated mice, confirming data obtained from PCR analysis. In kanamycin pretreated mice, chimerism was also found in spleen, liver and kidney (Figure 8B), revealing clusters of positive cells in some areas. Positivity for human DNA was never found in nontransplanted mice.

\section{Valuation of possible stem cell effects in other organs}

Histological analyses revealed no damage or altered structures in liver and kidney of transplanted mice (Figure 9). PCNA-positive proliferating cells were rare and randomly diffused in both liver (Figure 9B) and kidney (Figure 9D), with the same amounts in transplanted mice and controls. Apoptotic cells were almost 

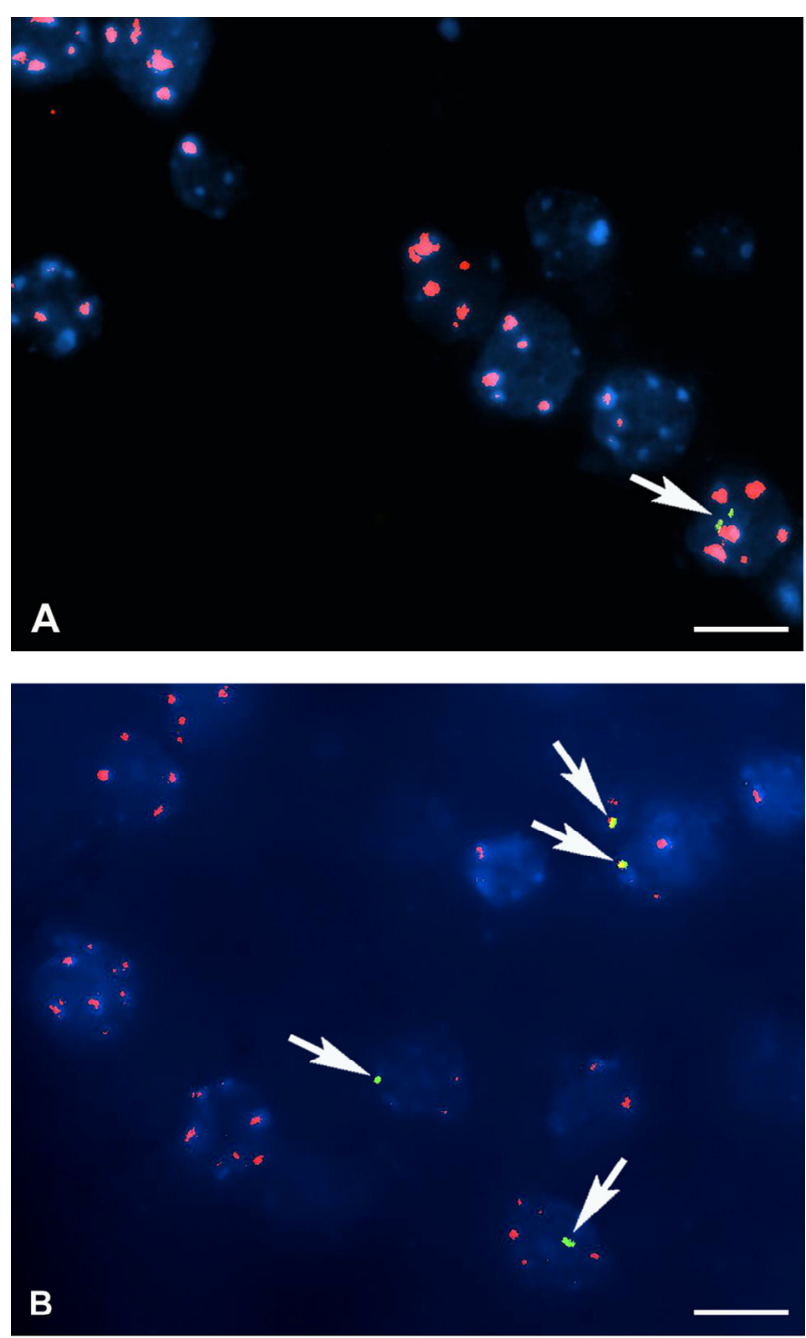

Figure 8. Dual color FISH staining of human (green) and mouse (red) pan-centromeric sequences. (A) Cochlear tissue of a group A mouse. (B) Liver of a group A mouse. Arrows indicate hybrid nuclei. Blue, nuclei stained by DAPI. Scale bar: $10 \mu \mathrm{m}$.

absent, also in group E mice, and no significant differences were observed in their density (Figure 9B and 9D).

\section{Discussion}

Adult MSCs have been isolated from various tissues and investigated as a potential tool in cell-based regenerative medicine. Among them, BM-MSCs and ADSCs have been extensively studied because of their regenerative capacity and high accessibility, but a direct comparison of their characteristics has not been sufficiently performed and the observed differences are still debated [29-33], thus it is still difficult to evaluate advantages and disadvantages of their clinical use.

Our data show that in vitro cultures of BMMSCs and ADSCs, despite their different origin, were very similar in proliferation rate and doubling time, and were homogeneous for expression of cell surface antigen markers for MSCs [34,35]. Even if the antigenic profiles generally satisfied the criteria for MSC identification [36], the expression of CD271 and HLADP-DQ-DR should be discussed in detail.

CD271 is described as a specific marker for identification of a clonogenic subpopulation of BMMSCs [37] and ADSCs [38] with high adipogenic and osteogenic differentiation capacity. Our cell cultures showed low levels of CD271 expression only at P0, similar to what was reported for freshly isolated bone marrow, amnion and chorion MSCs $[39,40]$. The expression of CD271 is known to be lost in further passages of in vitro MSC expansion $[39,40]$.

Also a low percentage of HLA-DP-DQ-DRpositive cells was exclusively detected at $\mathrm{P} 0$, even if HLA class II antigens are known to be expressed on the surface of adult MSCs only after stimulation, for example by interferon (IFN)- $\gamma$ [41]. Vishnubalaji et al. [35] compared the surface protein expression of BMMSCs and ADSCs, reporting a negative staining for HLA-DR in both types, but there are reports of cultured BM-MSCs expressing HLA-DR $[42,43]$.

Overall, the prolonged maintenance in culture probably affects MSC phenotypic characteristics, progressively reducing the expression of CD271 and HLA-DR [40,42,43].

In our study, both cell populations maintained multipotency, being able to differentiate in both adipogenic and osteogenic lineages, when maintained in the appropriate culture medium. Similar to previously described data [35], at day 7 BM-MSCs showed higher ALP activity compared with ADSCs. However, stem cells derived from umbilical cord blood showed an even faster osteogenesis than BM-MSCs [44]. Contrary to BM-MSCs, ADSCs showed higher ALP activity after 2 weeks. ADSCs were reported to maintain their multipotency at P25, after subculturing every 14 days [45]. They, therefore, appear more efficient than BM-MSCs at prolonged ex vivo expansion and times of osteogenic differentiation.

The adipogenic differentiation ability was generally comparable in BM-MSCs and ADSCs, but ADSCs showed a higher ability at day 4 , similar to what was previously reported [35].

Concerning the cochlea, this is the first study reporting the active role of human BM-MSCs in cochlear regeneration, whereas ADSCs have been recently investigated as a possible tool for therapy of acoustic lesions. Guinea pigs, injured by noise exposure followed by homologous ADSC implantation via the round window, partially recovered the auditory function after 7 days; however, in this study, the integrity of the cochlea after noise damage was preserved and no cochlear tissue regeneration was reported [46]. 


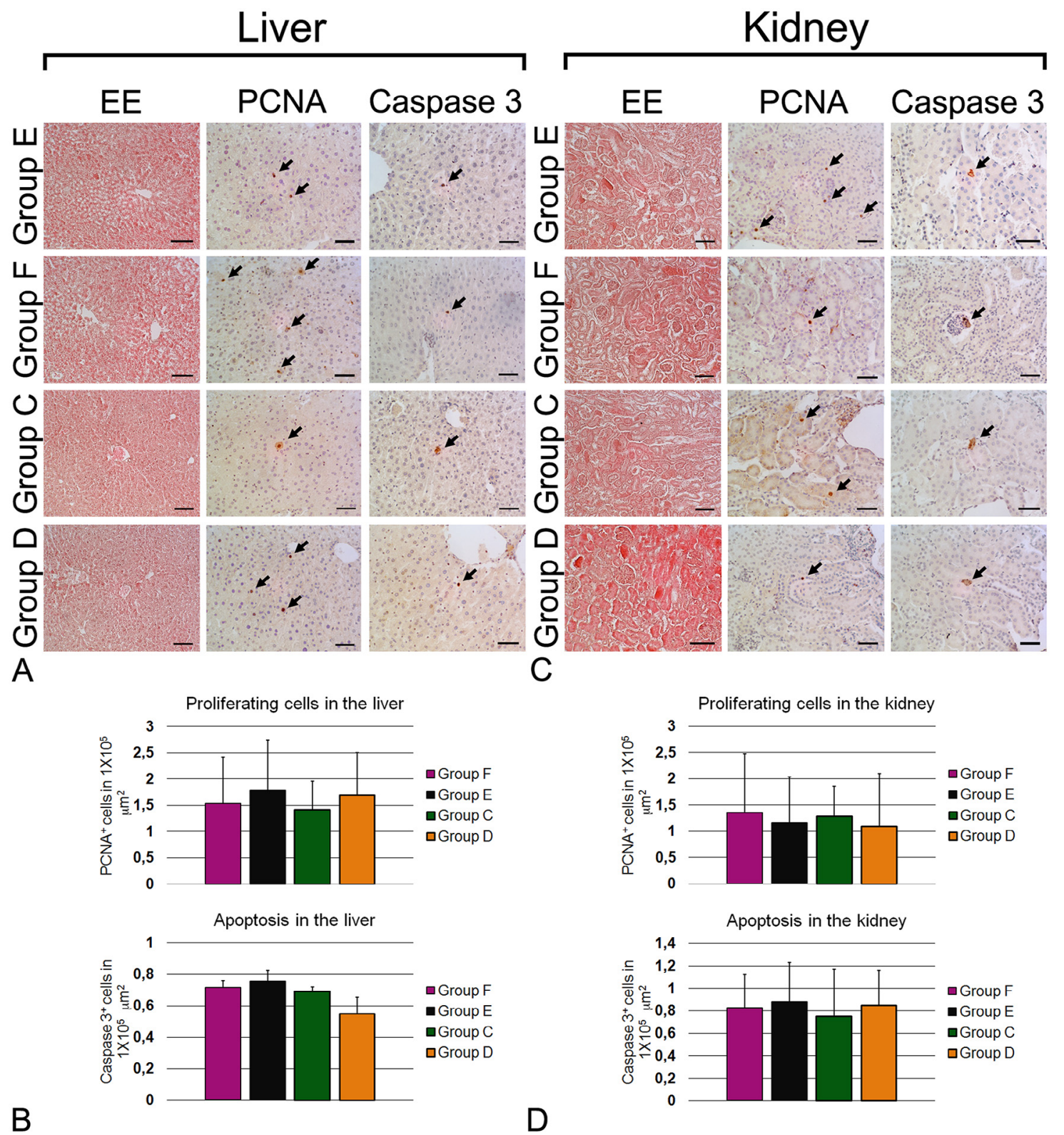

Figure 9. Micrographs of histological and immunohistochemical analyses of livers and kidneys from groups C, D, E and F. (A) Representative micrographs of liver. (B) Quantitative analysis of positive cells in the liver. (C) Representative micrographs of kidney. (D) Quantitative analysis of positive cells in the kidney. Arrows indicate positive cells. Scale bars: EE $100 \mu \mathrm{m}$, PCNA and Caspase-3 $50 \mu \mathrm{m}$.

In our study, all mice treated with kanamycin were deafened through severe and permanent damage, with structural alterations and loss of sensory auditory cells in the cochlea. These kanamycin-treated mice, when transplanted with BM-MSCs or ADSCs, showed fast cochlea repair due to regeneration and reconstruction of all damaged structures, including inner/outer support and hair cells, and auditory ganglion neurons.

An OC degeneration with significant hair cell loss, similar to kanamycin-induced damage, was observed in a mouse model with autoimmune hearing loss. After peritoneal ADSC transplantation for 6 weeks, regeneration of the cochlea was histologically observed, suggesting that ADSCs protected OC through a paracrine effect $[47,48]$.

Our findings suggest that BM-MSCs and ADSCs survived after transplantation and migrated to different organs. Our biomolecular results by HLA-DQ $\alpha 1$ PCR and human microsatellite detection correlated with those obtained by immunohistochemistry of HLA antigens, showing that acute tissue damage apparently enhanced recruitment.

The recruitment of some human BM-MSCs to rat cochleae injured with noise or ototoxic drugs has been previously documented [49]. Other reports demonstrated higher recruitment of MSCs in acutely damaged 
tissues [50-54], supporting the fact that stem cell engraftment depends on local micro-environmental cues. Interestingly, we observed numerous HLA-positive pericytes surrounding endothelial cells in capillaries and microvessels of transplanted mice. Similar results were reported in BM-MSCs derived from green fluorescent protein transgenic mice and IV injection into normal mice with cutaneous wounds; the stem cells migrated in the wound and expressed pericyte markers [55]. Our data agree with the hypothesis that the normal MSC location is the perivascular space and that pericytes correspond to the in vivo source of MSCs $[56,57]$. In injured tissues, pericytes are actually induced by systemic signals to become active MSCs, which secrete trophic, immunomodulatory or antimicrobial factors to re-establish the microenvironment and promote regeneration, then return to their native pericyte state [58].

Aminoglycosides are a class of antibiotics known to cause several adverse effects [59]. Among them kanamycin is known to damage the auditory, vestibular and renal systems [60]. However, mice showed resistance to kanamycin nephrotoxicity after a subcutaneous injection of $400-800 \mathrm{mg} / \mathrm{kg} 6$ days/week for 8 weeks [60]. To verify kanamycin adverse effects, in the present study we histologically examined two organs highly involved in xenobiotic metabolism, liver and kidney. No sign of morphological alteration was observed and apoptotic events were rare and similar in all groups analysed. Thus, we concluded that the drug did not affect the liver and kidney in our experimental conditions.

Stem cells are also known to have potential adverse effects, among which is tumor development [61]. However, clinical experience indicates that the administration of adult stem cells is not associated with tumor formation [62]. In our experimental conditions we evaluated the stem cell proliferative activity in liver and kidney; no increment was detected.

The DC-FISH data confirmed the detection of human MSCs in transplanted mice, with higher amounts in kanamycin-treated animals.

Moreover, the presence of hybrids between MSCs and endogenous mouse cells suggests that cell fusion is the principal fate of transplanted cells. It is possible that hybrids undergo unpredictable loss of genetic material after repeated cell divisions or as a function of time, because we did not observed multinucleated cells. However, the number of hybrid cells was difficult to ascertain because of the different phenotypes probably resulting from genetic rearrangements. Cell fusion was observed in other transplantation studies $[53,63,64]$, and, together with transdifferentiation, it was originally proposed as the principal mechanism by which transplanted stem cells promote tissue repair [65]. However, the number of hybrid cells detected in the cochlea was apparently low and absent in OC, where regeneration was documented, similar to what was previously described [47]. These data suggest that human MSCs do not direct-ly replace lost cells but exert their regenerative potential mainly through paracrine effects [66], probably by secreting trophic and antiapoptotic factors inducing the recipient cells to recover damage. This hypothesis is supported by previous data on a myocardial infarct model, in which injection of conditioned medium collected from hypoxic Akt-MSCs significantly limited infarct size, improving the cardiac performance [67].

In conclusion, we reported evidence that human BM-MSCs and ADSCs transplanted in kanamycindeafened mice equally contributed to morphological regeneration of cochlear tissues, probably inducing responses from resident cells by modulating the molecular micro-environments. The in vitro analyses confirmed the homogeneous characteristics of both cell types, but ADSC multipotency appeared to be more stable after prolonged expansion. The recruitment of both human MSCs was apparently proportional to the extent of damage, as previously reported in other models. Both cell types, therefore, could be used in developing innovative therapies for deafness based on regenerative medicine, but further investigations are required about their paracrine activity and their effects on resident cells.

\section{Acknowledgments}

This work was supported by the Ministry of Education, University and Research (MIUR) R110-RFO14FRA4.

Disclosure of interests: The authors have no commercial, proprietary or financial interest in the products or companies described in this article.

\section{References}

[1] Ciorba A, Astolfi L, Martini A. Otoprotection and inner ear regeneration. Audiol Med 2008;6:170-5.

[2] Revoltella RP, Papini S, Rosellini A, Michelini M, Franceschini $\mathrm{V}$, Ciorba A, et al. Cochlear repair by transplantation of human cord blood CD133+ cells to nod-scid mice made deaf with kanamycin and noise. Cell Transplant 2008;17:665-78.

[3] Teo AK, Vallier L. Emerging use of stem cells in regenerative medicine. Biochem J 2010;428:11-23.

[4] Gunewardene N, Dottori M, Nayagam BA. The convergence of cochlear implantation with induced pluripotent stem cell therapy. Stem Cell Rev 2012;8:741-54.

[5] Simoni E, Orsini G, Chicca M, Bettini S, Franceschini V, Martini A, et al. Regenerative medicine in hearing recovery. Cytotherapy 2017;19(8):9-15.

[6] Reekmans K, Praet J, Daans J, Reumers V, Pauwels P, Van der Linden A, et al. Current challenges for the advancement of neural stem cell biology and transplantation research. Stem Cell Rev 2012;8(1):262-78. 
[7] Palmgren B, Jiao Y, Novozhilova E, Stupp SI, Olivius P. Survival, migration and differentiation of mouse tau-GFP embryonic stem cells transplanted into the rat auditory nerve. Exp Neurol 2012;235(2):599-609.

[8] Zhao LD, Li L, Wu N, Li DK, Ren LL, Guo WW, et al. Migration and differentiation of mouse embryonic stem cells transplanted into mature cochlea of rats with aminoglycosideinduced hearing loss. Acta Otolaryngol 2013;133(2):136-43.

[9] Nishimura K, Nakagawa T, Sakamoto T, Ito J. Fates of murine pluripotent stem cell-derived neural progenitors following transplantation into mouse cochleae. Cell Transplant 2012;21(4):763-71.

[10] Tan CQ, Gao X, Guo L, Huang H. Exogenous IL-4-expressing bone marrow mesenchymal stem cells for the treatment of autoimmune sensorineural hearing loss in a guinea pig model. Biomed Res Int 2014;2014:856019.

[11] Watada Y, Yamashita D, Toyoda M, Tsuchiya K, Hida N, Tanimoto A, et al. Magnetic resonance monitoring of superparamagnetic iron oxide (SPIO)-labeled stem cells transplanted into the inner ear. Neurosci Res 2015;95:21-6.

[12] Li H, Liu H, Heller S. Pluripotent stem cells from the adult mouse inner ear. Nat Med 2003;9(10):1293-9.

[13] Lang H, Ebihara Y, Schmiedt RA, Minamiguchi H, Zhou D, Smythe $\mathrm{N}$, et al. Contribution of bone marrow hematopoietic stem cells to adult mouse inner ear: mesenchymal cells and fibrocytes. J Comp Neurol 2006;496(2):187-201.

[14] Kamiya K, Fujinami Y, Hoya N, Okamoto Y, Kouike H, Komatsuzaki R, et al. Mesenchymal stem cell transplantation accelerates hearing recovery through the repair of injured cochlear fibrocytes. Am J Pathol 2007;171(1):214-26.

[15] Tan BTG, Lee MMG, Ruan R. Bone marrow-derived cells that home to acoustic deafened cochlea preserved their hematopoietic identity. J Comp Neurol 2008;509:167-79.

[16] Hass R, Kasper C, Böhm S, Jacobs R. Different populations and sources of human mesenchymal stem cells (MSC): a comparison of adult and neonatal tissue-derived MSC. Cell Commun Signal 2011;9:12.

[17] Naderi-Meshkin H, Bahrami AR, Bidkhori HR, Mirahmadi M, Ahmadiankia N. Strategies to improve homing of mesenchymal stem cells for greater efficacy in stem cell therapy. Cell Biol Int 2015;39(1):23-34.

[18] DiMarino AM, Caplan AI, Bonfield TL. Mesenchymal stem cells in tissue repair. Front Immunol 2013;4(201):1-9.

[19] Dal Pozzo S, Urbani S, Mazzanti B, Luciani P, Deledda C, Lombardini L, et al. High recovery of mesenchymal progenitor cells with non-density gradient separation of human bone marrow. Cytotherapy 2010;12(5):579-86.

[20] Urbani S, Caporale R, Lombardini L, Bosi A, Saccardi R. Use of CFDA-SE for evaluating the in vitro proliferation pattern of human mesenchymal stem cells. Cytotherapy 2006;8(3):243-53.

[21] Mazzanti B, Aldinucci A, Biagioli T, Barilaro A, Urbani S, Dal Pozzo S, et al. Differences in mesenchymal stem cell cytokine profiles between MS patients and healthy donors: implication for assessment of disease activity and treatment. J Neuroimmunol 2008;199(1-2):142-50.

[22] Beresford JN, Gallagher JA, Russell RG. 1,25Dihydroxyvitamin D3 and human bone-derived cells in vitro: effects on alkaline phosphatase, type I collagen and proliferation. Endocrinology 1986;119(4):1776-85.

[23] Stanford CM, Jacobson PA, Eanes ED, Lembke LA, Midura RJ. Rapidly forming apatitic mineral in an osteoblastic cell line (UMR 106-01 BSP). J Biol Chem 1995;270(16):9420-8.

[24] Danet GH, Lee HW, Luongo JL, Simon MC, Bonnet DA. Dissociation between stem cell phenotype and NOD/SCID repopulating activity in human peripheral blood CD34(+) cells after ex vivo expansion. Exp Hematol 2001;29(12):1465-73.
[25] Zheng JL, Gao WQ. Analysis of rat vestibular hair cell development and regeneration using calretinin as an early marker. J Neurosci 1997;17(21):8270-82.

[26] Almeida-Porada G, El Shabrawy D, Porada C, Zanjani ED. Differentiative potential of human metanephric mesenchymal cells. Exp Hematol 2002;30:1454-62.

[27] Ricci U, Sani I, Guarducci S, Biondi C, Pelagatti S, Lazzerini $\mathrm{V}$, et al. Infrared fluorescent automated detection of thirteen short tandem repeat polymorphisms and one genderdetermining system of the CODIS core system. Electrophoresis 2000;21(17):3564-70.

[28] Michelini M, Papini S, Rosellini A, Noia G, Ligato MS, Mancuso S, et al. Prolonged human/sheep cellular chimerism following transplantation of human hemopoietic stem cells into the ewe celomic cavity. Int J Dev Biol 2008;52:365-70.

[29] Im GI, Shin YW, Lee KB. Do adipose tissue-derived mesenchymal stem cells have the same osteogenic and chondrogenic potential as bone marrow-derived cells? Osteoarthritis Cartilage 2005;13(10):845-53.

[30] Noël D, Caton D, Roche S, Bony C, Lehmann S, Casteilla L, et al. Cell specific differences between human adiposederived and mesenchymal-stromal cells despite similar differentiation potentials. Exp Cell Res 2008;314(7):157584.

[31] Danišovič L, Boháč M, Zamborský R, Oravcová L, Provazníková $Z$, Csöbönyeiová $M$, et al. Comparative analysis of mesenchymal stromal cells from different tissue sources in respect to articular cartilage tissue engineering. Gen Physiol Biophys 2016;35(2):207-14.

[32] Sullivan MO, Gordon-Evans WJ, Fredericks LP, Kiefer K, Conzemius MG, Griffon DJ. Comparison of mesenchymal stem cell surface markers from bone marrow aspirates and adipose stromal vascular fraction sites. Front Vet Sci 2016;2:82.

[33] Woo DH, Hwang HS, Shim JH. Comparison of adult stem cells derived from multiple stem cell niches. Biotechnol Lett 2016;38(5):751-9.

[34] Mafi P, Hindocha S, Mafi R, Griffin M, Khan WS. Adult mesenchymal stem cells and cell surface characterization - a systematic review of the literature. Open Orthop J 2011;5(Suppl. 2):253-60.

[35] Vishnubalaji R, Al-Nbaheen M, Kadalmani B, Aldahmash A, Ramesh T. Comparative investigation of the differentiation capability of bone-marrow- and adipose-derived mesenchymal stem cells by qualitative and quantitative analysis. Cell Tissue Res 2012;347(2):419-27.

[36] Dominici M, Le Blanc K, Mueller I, Slaper-Cortenbach I, Marini F, Krause D, et al. Minimal criteria for defining multipotent mesenchymal stromal cells. The International Society for Cellular Therapy position statement. Cytotherapy 2006;8(4):315-17.

[37] Quirici N, Soligo D, Bossolasco P, Servida F, Lumini C, Deliliers GL. Isolation of bone marrow mesenchymal stem cells by anti-nerve growth factor receptor antibodies. Exp Haematol 2002;30:783-91.

[38] Quirici N, Scavullo C, de Girolamo L, Lopa S, Arrigoni E, Deliliers GL, et al. Anti-L-NGFR and -CD34 monoclonal antibodies identify multipotent mesenchymal stem cells in human adipose tissue. Stem Cells Dev 2010;19:915-25.

[39] Soncini M, Vertua E, Gibelli L, Zorzi F, Denegri M, Albertini $\mathrm{A}$, et al. Isolation and characterization of mesenchymal cells from human fetal membranes. J Tissue Eng Regen Med 2007;1(4):296-305.

[40] Rojewski MT, Weber BM, Schrezenmeier H. Phenotypic characterization of mesenchymal stem cells from various tissues. Transfus Med Hemother 2008;35(3):168-84.

[41] Le Blanc K, Ringdén O. Immunobiology of human mesenchymal stem cells and future use in hematopoietic stem 
cell transplantation. Biol Blood Marrow Transplant 2005;11(5):321-34.

[42] Jones EA, Kinsey SE, English A, Jones RA, Straszynski L, Meredith DM, et al. Isolation and characterization of bone marrow multipotential mesenchymal progenitor cells. Arthritis Rheum 2002;46(12):3349-60.

[43] Dighe PA, Viswanathan P, Mruthunjaya AK, Seetharam RN. Effect of bFGF on HLA-DR expression of human bone marrow-derived mesenchymal stem cells. J Stem Cells 2013;8(1):43-57.

[44] Baksh D, Yao R, Tuan RS. Comparison of proliferative and multilineage differentiation potential of human mesenchymal stem cells derived from umbilical cord and bone marrow. Stem Cells 2007;25(6):1384-92.

[45] Zhu Y, Liu T, Song K, Fan X, Ma X, Cui Z. Adipose-derived stem cell: a better stem cell than BMSC. Cell Biochem Funct 2008;26(6):664-75.

[46] Fetoni AR, Lattanzi W, Eramo SL, Barba M, Paciello F, Moriconi C, et al. Grafting and early expression of growth factors from adipose-derived stem cells transplanted into the cochlea, in a Guinea pig model of acoustic trauma. Front Cell Neurosci 2014;8:334.

[47] Zhou Y, Yuan J, Zhou B, Lee AJ, Lee AJ, Ghawji M Jr, et al. The therapeutic efficacy of human adipose tissue-derived mesenchymal stem cells on experimental autoimmune hearing loss in mice. Immunology 2011;133(1):133-40.

[48] Yoo TJ, Du X, Zhou B. The paracrine effect of mesenchymal human stem cells restored hearing in $\beta$-tubulin induced autoimmune sensorineural hearing loss. Hear Res 2015;330(Pt A):57-61.

[49] Choi BY, Song JJ, Chang SO, Kim SU, Oh SH. Intravenous administration of human mesenchymal stem cells after noiseor drug-induced hearing loss in rats. Acta Otolaryngol 2012;132(Suppl. 1):S94-102.

[50] Coronel MF, Musolino PL, Villar MJ. Selective migration and engraftment of bone marrow mesenchymal stem cells in rat lumbar dorsal root ganglia after sciatic nerve constriction. Neurosci Lett 2006;405(1-2):5-9.

[51] Chen J, Park HC, Addabbo F, Ni J, Pelger E, Li H, et al. Kidney-derived mesenchymal stem cells contribute to vasculogenesis, angiogenesis and endothelial repair. Kidney Int 2008;74(7):879-89.

[52] Franceschini V, Bettini S, Pifferi S, Rosellini A, Menini A, Saccardi R, et al. Human cord blood CD133+ stem cells transplanted to nod-scid mice provide conditions for regeneration of olfactory neuroepithelium after permanent damage induced by dichlobenil. Stem Cells 2009;27(4):82535 .
[53] Franceschini V, Bettini S, Pifferi S, Menini A, Siciliano G, Ognio E, et al. Transplanted human adipose tissue-derived stem cells engraft and induce regeneration in mice olfactory neuroepithelium in response to dichlobenil subministration. Chem Senses 2014;39(7):617-29.

[54] Eseonu OI, De Bari C. Homing of mesenchymal stem cells: mechanistic or stochastic? Implications for targeted delivery in arthritis. Rheumatology (Oxford) 2015;54(2):210-18.

[55] Sasaki M, Abe R, Fujita Y, Ando S, Inokuma D, Shimizu H. Mesenchymal stem cells are recruited into wounded skin and contribute to wound repair by transdifferentiation into multiple skin cell type. J Immunol 2008;180(4):2581-7.

[56] Crisan M, Yap S, Casteilla L, Chen C-W, Corselli M, Park TS, et al. A perivascular origin for mesenchymal stem cells in multiple human organs. Cell Stem Cell 2008;3:301-13.

[57] Da Silva Meirelles L, Caplan AI, Nardi NB. In search of the in vivo identity of mesenchymal stem cells. Stem Cells 2008;26:2287-99.

[58] Murphy MB, Moncivais K, Caplan AI. Mesenchymal stem cells: environmentally responsive therapeutics for regenerative medicine. Exp Mol Med 2013;45:e54.

[59] Prayle A, Watson A, Fortnum H, Smyth A. Side effects of aminoglycosides on the kidney, ear and balance in cystic fibrosis. Thorax 2010;65:654-8.

[60] Perdue VP, Burright RG, Donovick PJ. Kanamycin effects on vestibular, auditory, and renal function in mice. Bull Psychon Soc 1984;22(3):241-3.

[61] Lodi D, Iannitti T, Palmieri B. Stem cells in clinical practice: applications and warnings. J Exp Clin Cancer Res 2011;30:9.

[62] Herberts CA, Kwa MSG, Hermsen HPH. Risk factors in the development of stem cell therapy. J Transl Med 2011;9:29.

[63] Johansson CB, Youssef S, Koleckar K, Holbrook C, Doyonnas R, Corbel SY, et al. Extensive fusion of haematopoietic cells with Purkinje neurons in response to chronic inflammation. Nat Cell Biol 2008;10(5):575-83.

[64] Kemp K, Gordon D, Wraith DC, Mallam E, Hartfield E, Uney J, et al. Fusion between human mesenchymal stem cells and rodent cerebellar Purkinje cells. Neuropathol Appl Neurobiol 2011;37(2):166-78.

[65] Zech NH. Plasticity of stem cells: cell-fusion versus transdifferentiation. J Reproduktionsmed Endokrinol 2005;2(4):239-45.

[66] Liang X, Ding Y, Zhang Y, Tse HF, Lian Q. Paracrine mechanisms of mesenchymal stem cell-based therapy: current status and perspectives. Cell Transplant 2014;23(9):1045-59.

[67] Gnecchi M, He H, Noiseux N, Liang OD, Zhang L, Morello $\mathrm{F}$, et al. Evidence supporting paracrine hypothesis for Aktmodified mesenchymal stem cell-mediated cardiac protection and functional improvement. FASEB J 2006;20(6):661-9. 